\title{
Franchisee Associations: Strategic Focus Or Response to Franchisor Opportunism*
}

\author{
Benjamin Lawrence \\ Boston University
}

\section{Patrick J. Kaufmann \\ Boston University}

Benjamin Lawrence is a Doctoral Candidate and Patrick J. Kaufmann is a Professor and Everett W. Lord Distinguished Faculty Scholar at Boston University’s School of Management, 595 Commonwealth Ave, Boston MA 02215.

Address correspondence to Benjamin Lawrence, Doctoral Candidate, Boston University, School of Management, Marketing Department, 595 Commonwealth Ave, Boston MA, 02215 benl@bu.edu

*An earlier version of this paper under a different title was presented at the 2009 International Society of Franchising Conference, San Diego, CA. 


\title{
Franchisee Associations: Strategic Focus or Response to Franchisor Opportunism
}

\begin{abstract}
This paper examines some of the antecedents, processes and effects of independent franchisee associations (IndFAs) and the reactions of franchisors to their organization. Specifically, we draw on various literatures to pose propositions relating to the following research questions: (1) Are there fundamental differences between associations whose focus is based on disagreements relating to strategic actions of the franchisor and those whose focus is perceived opportunistic behavior on the part of the franchisor? (2) Does the way these IndFAs are treated by the franchisor - post inception - affect members' identification with the group and/or franchisor? (3) Does the existence of a franchisee advisory council influence the willingness of the a franchisor to legitimize an IndFA? (4) How does the size of the IndFA influence identification? We then present a conceptual model and use two illustrative examples from the business literature to explore our propositions.
\end{abstract}

Key Words: Independent Franchisee Association, Advisory Council, Franchising, Identity, Identification 


\section{Franchisee Associations: Strategic Focus or Response to Franchisor Opportunism}

On Nov. 27, 2006, Bhupinder Baber, a former Quiznos franchisee, entered a Quiznos restaurant and committed suicide. Before his death, Mr. Baber had struggled to win a civil lawsuit against Quiznos for false representation and had his franchise contract terminated when he created an independent franchisee association (IndFA) called the “Quiznos Subs Franchise Association” (Creswell 2007). The following are excerpts from Mr. Baber’s suicide note.

"I have struggled hard and did the best I could to create a voice for the franchisees in the system and to create a "support system" for the franchisees, which does not exist, and to fight the injustices of this franchise system. Not to bring the system down, but only to make it fair...

....How can a common individual like me and those like me in similar circumstances, there are thousands, with limited resources get justice? I believe there will be justice. But it will be too late for me...

....The IFA (International Franchise Association) is the umbrella entity that, along with individual Franchisors, has enough money and power to buy the legislation that protects the Franchisor, and exploits the Franchisee. Fair and just legislation, that would level the playing field, never sees the light of day...”

The popular press has documented similar cases of conflict between franchisees and franchisors as GNC (Hays 2001), Blimpie (Hayes 2004), Burger King (Berg 1988), and Blockbuster

(Deutsch 1988) franchisees have taken franchisors to court to battle for their rights. Clearly Mr. Baber's story depicts an extreme example of such franchisor/franchisee conflict. However, it also represents a growing and increasingly visible political body within franchise systems, the grassroots IndFA which represents the rights of franchisees during such conflict.

As such IndFAs may act as a countervailing power, as franchisees when faced with the perceived overwhelming power of the franchisor feel compelled to form a mitigating positive force (Galbraith 1956). Such coordinated resistance, enabled by a cohesive unit embodied in a IndFA, 
franchisees often wield sufficient countervailing power to ensure that they receive a fair deal from their franchisors (Deutsch 1988). Other forms of such countervailing power include law suits, trade unions, lobbying groups, or citizen organizations. Within franchise systems, one way of increasing power is multi-unit franchising, as ownership of a large number of stores provides an individual franchisee with greater influence within the system (Grünhagen and Mittelstaedt 2002). Legislative action, may provide another way of counteracting the leverage the franchisor has on franchisee-franchisor relationship (eg., Brickley et al. 2003).

Even McDonalds, the prototypical franchisor, has encountered an IndFA. In 1996 McDonalds franchisees formed Consortium Members Inc. with the aim of monitoring McDonalds’s corporate activities (Hamstra 1997; Kramer 1996). This was the first such independent franchisee group to be established at McDonalds since the mid 70s. Consortium Members, Inc. became an independent alternative to the (then) existing McDonalds franchisee advisory council (FAC) called the National Operators Advisory Board (NOAB) (Kramer 1996). While both represent franchisee interests, IndFAs and FACs are significantly different entities. FACs are corporate funded and supported groups typically made up of appointed or approved franchisees; while IndFAs are independent non-profit organizations that are set up by franchisees in an effort to foster community and gain power in the system. Though such ideal forms do exist, in general, most associations exist along a continuum from fully captive to fully independent entities.

In this paper, we examine some of the antecedents, processes and effects of IndFAs and the reactions of franchisors to their organization. Specifically, we draw on various literatures to pose propositions relating to the following research questions: (1) Are there fundamental differences between associations whose focus is based on disagreements relating to strategic actions of the 
franchisor and those whose focus is perceived opportunistic behavior on the part of the franchisor? (2) Does the way these IndFAs are treated by the franchisor - post inception - affect members' identification with the group and/or franchisor? (3) Does the existence of a FAC influence the willingness of a franchisor to legitimize an IndFA? (4) How does the size of the IndFA influence identification? We then use two illustrative examples from the business literature to explore our propositions.

\section{Franchisee Associations}

As mentioned above, FACs anchor the completely captive end of the spectrum of franchisee associations. Their unique feature is that their existence and membership are typically under complete control of the franchisor. For example, in 1999 McDonalds unilaterally disbanded the long standing FAC, the NOAB, and created the National Leadership Council, a successor FAC whose membership includes high profile McDonalds’ franchisee representatives serving 2-3 year terms (Staff 1998). Contrast this with the independent association Consortium Members, Inc. whose membership was made up of anonymous McDonalds' franchisees. Although a FAC is often formed with the expressed goal of representing the interests of franchisees and often have elected franchisees to perform this task they are often viewed by franchisees as puppets of the franchisor. Without the ability to challenge the franchisors' authority, FACs are often viewed as merely an extension of the franchisor without a true independent identity or function.

Unlike FACs that are fully sanctioned and often funded by the franchisor, wholly independent IndFAs with no ties whatsoever to the franchisor anchor the other end of the continuum. These associations may not be sanctioned or even recognized by the franchisor and their governance is completely free of input from the franchisor. 
“A franchisee association is an independent organization of franchisees. It is distinguished from advisory councils or other entities sponsored or funded by the franchisor. Some associations have been funded by the franchisor, but the resulting inhibition of independent action on behalf of franchisee interests makes such organizations at best a hybrid, and at worst completely compromised in their ability to represent franchisee interests.” (www.franchisee.org).

An example of a completely independent franchisee association would be the Brown Board within the Mail Boxes Etc. / UPS Stores system. IndFAs arrayed along this continuum would represent franchisees from a wide range of well known franchise systems, including for example, A\&W, Econolodge, Pizza Hut, KFC, Kwik Copy, Holiday Inns, Merry Maids, Meineke, Denny's, Sonic, Little Caesar's, Domino's, 7-Eleven, Burger King, Hooters, Hardee’s, TCBY, Subway, and Dairy Queen among many others.

Some of these IndFAs as organizations, and/or their members as individual franchisees, are also members of one of the overarching franchisee advocate organizations such as the American Association of Franchisees and Dealers (AAFD) or the Coalition of Franchisee Associations (CFA). Another organization that tried to improve business conditions and to protect franchisees’ economic interests by balancing power in the franchise relationship was the American Franchisee Association (AFA), which failed to maintain momentum and subsequently disbanded. Groups such as the AFA have stated that the industry’s main trade group, the International Franchise Association, which now welcomes franchisee members, essentially works to accomplish franchisor interests, "The International Franchise Association is really the International Franchisor Association...It was formed so franchisors could meet without the input of franchisees” (Allen 1992). Interestingly, these groups also claim that they work to protect the franchise relationship thus benefiting both the franchisor and franchisee. Bob Purvin, Chairman of the AAFD who has announced that he will soon be stepping down from his leadership role, has stated that the most important characteristic for a potential franchisee to evaluate a franchise 
system is the existence of an IndFA and one that the franchisor actively communicates with. The CFA was formed in 2007 and its members include some of the largest franchisee associations including Dunkin Donuts, 7 eleven, Pizza Hut, and Burger King. The CFA’s mission is to "leverage the collective strengths of franchisee associations for the benefit of the franchisee community” and they accomplish this by lobbying state and national government, by promoting franchisee education and training, executive leadership development and collective buying opportunities. (thecfainc.com)

Research on relationships within franchising has focused almost exclusively on the dyadic relationship between franchisee and franchisor (Oxenfeldt and Kelly 1968; Rubin 1978). Relationships among franchisees have not been considered as influential factors on the system. It is not surprising therefore, that academic research has rarely focused on the impact of franchisee associations of any kind, let alone the unique characteristics of IndFAs. Nevertheless, it is our contention that these groups are a significant feature of many franchise systems and contribute substantially to the climate of the franchisor-franchisee relationship. How these groups are formed and how they affect the franchisor/franchisee relationship, therefore, is an important topic for franchise research.

\section{Franchisee Group Formation}

Within the fields of social psychology, sociology, and organizational behavior there is substantial research on group formation and maintenance. In their seminal work on group dynamics Cartwright and Zander (1968 p.46) define a group as “a collection of individuals who have relations with one another that make them interdependent to some significant degree. As so defined, the term group refers to a class of social entities having in common the property of 
interdependence among their constituent members.” The authors list the characteristics of individuals that belong to groups. Group members engage in frequent interactions; define themselves as members; are defined by others as belonging to the same group; share norms; participate in interlocking roles; have a collective perception of unity; and tend to act in a unitary manner toward the environment. Cartwright and Zander (1968) also propose that when groups are deliberately formed it is because of "the judgment by one or more people that a collection of individuals can accomplish some purpose (or do so at a level of efficiency) not otherwise possible.” This deliberate formation may involve the formation of work groups (e.g., the franchise system itself), problem-solving groups (e.g., unions or IndFAs), social action groups, mediating groups (e.g., AFAs), legislative groups, and/or client groups.

Like union formation that is predicated on the protection and improvement of working conditions, IndFA formation results from deliberate formation and problem recognition by franchisees. Over time, if the purpose for the IndFA's formation continues, it can be expected that the ostensible focus of the IndFA will retain the same problem solving characteristics. However, there are instances when the groups' initial impetus for formation will be different than its current focus. An example of this evolution would be the case where a franchisee group forms in response to opportunistic actions of a franchisor but over time is integrated into the informal (and on some occasions formal) management of the franchise system so that its focus shifts to an attempt to influence the strategic and tactical direction of the system. Or the alternative case where the IndFA's initial focus was strategic but subsequent actions by the franchisor occasioned a shift to a focus on perceived opportunistic behavior. So although the reasons for the IndFA's formation play an important role in the initial focus of the association, it 
is important to note that in this paper our primary variable of interest is the current problem solving focus of the IndFA.

\section{IndFA Focus}

Among the many types of problems that arise in a franchise system and which may precipitate the formation and influence the current problem solving focus of IndFAs are 1) disagreements over the strategic direction of the franchise system and 2) disagreements involving perceptions that the franchisor is acting opportunistically, i.e., acting in a harmful or destructive way and disregarding the interests of the franchisees. In each case these disagreements reflect underlying conflict within the system. However, the type of disagreement, and thus the nature of the IndFA's focus, in each case are quite different. Strategic disagreements may occur due to differing perceptions of reality, conflict over decision domains, or the competing goals of franchisors and franchisees. For example, an IndFA may form when a group of franchisees disagrees with the franchisor on topics such as brand stewardship, strategic initiatives, or resource allocation. The resultant IndFA can provide a channel through which to voice these concerns and argue the perspective of the franchisee. Even though these disagreements may create conflict among the IndFA and the franchisor the overarching goal of system profitability and growth are maintained. IndFAs, whose focus is the resolution of these strategic issues, we define as having a strategic focus.

By contrast, IndFAs may also be focused on the perceived opportunistic actions of the franchisor. For example, an IndFA may form when a group of franchisees feels the franchisor is making unilateral decisions directly harmful to the franchisees and the resultant IndFA provides a mechanism to protect franchisee rights. Deceptive contract agreements, misrepresentation of 
the franchise business case, unfair cancellation of contracts, unfair profit distribution and the use of coercive power are examples of opportunistic behaviors. IndFAs, addressing these kinds of concerns we define as having a franchisor's opportunism focus. This leads to the following propositions related to IndFAs:

P1: IndFA focus can result from strategic disagreements dealing issues such as brand stewardship, strategic partnerships, and resource allocation.

P2: IndFA focus can result from perceptions of opportunistic behavior of the franchisor including unfair contract agreements, misrepresentation of the franchise business case, unfair cancellation of contracts, unfair profit distribution, and the use of coercive power.

\section{Social Identity and IndFA Communities}

Franchisee groups like the franchise system itself or IndFAs often take on the characteristics of communities. Communities are based partly on “consciousness of kind” (Muniz and O'Guinn 2001) an awareness of the distinctiveness of one's group and an identification with its members. A major component of the formation of communities is intergroup bias, the tendency to evaluate an in-group in which one is a member over an out-group in which one is not a member.

Of the various theories in psychology that have been used to explain intergroup bias including terror management theory (Greenberg et al. 1986), optimal distinctiveness theory (Brewer 1991), and subjective uncertainty reduction theory (Hogg and Abrams 1993); it is social identity theory (Tajfel and Turner 1979) that provides the most useful framework through which we can investigate the potential conflict arising between IndFA and franchisor. Social identity theory 
posits that individuals derive a portion of their self concept from membership in various groups. It argues that in addition to individual identity traits (i.e. I am hard working), identity derived from affiliation with various groups including those based on demographic or cultural interests (i.e. I am a member of Greenpeace) play a role in defining the self. Applying social identity theory, organizational theorists have studied the identification between individuals and organizations (Dutton et al. 1994; Mael and Ashforth 1992). Dutton et al. (1994), argue that such identification is driven by perceived congruence of group and individual self concepts, the ability to support self esteem, and the ability to create distinctiveness. By extension it may be expected that franchisees social identity will be derived both from their membership in the franchise system itself, but also from membership in franchisee organizations such as an IndFA. At question is whether the franchisee will also identify with the franchisor as leader of the system.

\section{Factors Influencing Group Identification}

At the core of social identity theory are three principles: categorization, identification, and comparison. Each strengthens the individual's identification with the focal group.

Categorization relates to the action of categorizing individuals, male vs. female, rich vs. poor.

“We are franchisees; they are the franchisor”. Identification relates to an individual's action of creating in-groups, groups in which they belong and relate to, and out-groups from which they feel apart. "We franchisees all care about outlet profits, but the franchisor only cares about sales”. Comparison involves the active contrast between in-groups and out-groups and the favoring of characteristics of the in-group. "We franchisees have different goals than the franchisor”. Research has shown that group favoritism and out-group discrimination occurs even in groups with “minimal” identification where no social interaction or economic interest 
exists between group members (Tajfel 1970). In groups where there is a significant economic interest such as an IndFA, it might be expected that these out-group discrimination processes will be highly salient to the members. Thus, to truly understand the relevant relationships within franchise systems, it is important to examine who franchisees identify as their in-groups and outgroups. Here our focus is on whether franchisees identify with the IndFAs or the franchisor noting that the entity with which the franchisee identifies may have significant implications for the management of the franchise system.

Franchisees (as agents) face both output and input controls, both of which are designed to align their behavior with the goals of the franchisor (as principle). Strong identification with the franchisor my act as an additional control mechanism to align interests. However, instead of indentifying with the franchisor, franchisees may identify strongly with their individual outlet, other franchisees, or an IndFA. Though researchers have investigated the impact of strong consumer-company relationships resulting from consumers’ identification with the firm (Ahearne et al. 2005; Bhattacharya et al. 1995; Bhattacharya and Sen 2003) the impact of an IndFA as an alternative to the franchisor for purposes of franchisee identification is unknown.

It does seem clear that when franchisees are members of IndFAs whose focus is on the perceived opportunistic acts of the franchisor the heart of that focus will emphasize the divergence of interests between the franchisor and the franchisees. This exacerbates out-group bias and will strengthen the franchisees identification with the IndFA. On the other hand, when the focus of the IndFA is on the strategic direction of the system, the overall goal is to bring the franchisees and franchisor into greater alignment of interests. This will act to ameliorate the out-group bias and strengthen the franchisees identification (or at least lessen the dis-identification) with the 
franchisor. Similarly, to the extent that the strength of the franchisee's identification with the IndFA depends on the element of comparison, an IndFA focus on strategic disagreement should serve to weaken the franchisee’s identification with the IndFA. This leads to the following proposition related to IndFAs:

P3: When compared to IndFAs whose focus is strategic; members of an IndFA whose focus is on franchisor opportunism will manifest stronger identification with the IndFA and lower identification with the franchisor.

\section{The Moderating Function of Franchisor Actions}

Several techniques have been studied to reduce group identification and the subsequent intergroup conflict that arises. Sherif's (1961) studies on group conflict found that it is possible to reduce categorization and the resulting intergroup conflict via recategorization, decategorization, and mutual differentiation strategies (Gaertner et al. 2000). Recategorization involves developing a higher order, superordinate, inclusive grouping that reduces intergroup conflict (Gaertner et al. 2000). For example, in franchising mutual recognition of a competitive threat might serve to reduce the in-group out-group bias by emphasizing that both franchisee and franchisor are members of the franchise system which is under threat. Decategorization involves the replacement of group identification with viewing individuals as separate individuals (Gaertner et al. 2000). Such decategorization is enabled when individuals interact on a personal level and cooperate interdependently with those from identified out-groups (Bettencourt et al. 1992; Brewer 1988). In franchising, this might be accomplished through the involvement of individual franchisees in franchisor-run franchisee advisory councils. In FACs, franchisees interact as individuals with franchise system executives and the social distance between the two groups is often diminished. Mutual differentiation (Hewstone and Brown 1986) involves an 
emphasis on salient group differences and cooperative interdependence. This approach focuses on mutual goals and the relative strengths of each group as contributors to this win-win situation. In the franchising context this might take the form of recognizing the unique contribution of each member to the franchise system (e.g., emphasizing franchisee knowledge of local markets and customers and the franchisor's capabilities related to efficiencies of scale).

The level of intergroup bias between IndFA members and their franchisor should be affected by the extent to which franchisees perceive higher order goals shared with the franchisor, interact with the franchisor as individuals, or see interdependence with the franchisor as salient (Gaertner et al. 2000). Thus, franchisors can actively employ these bias reduction techniques to impact the social identification of their franchisees. Firstly, by integrating the IndFA into the strategic decision making process of the firm they can emphasize higher order goals such as competition that help unify IndFA and franchisor missions. Secondly, they can work to individuate the relationship with IndFA member franchisees through direct communication with IndFAs members. Thirdly, the franchisor can increase communication and contact with the IndFA community by attending IndFA conferences and developing channels of legitimate communication.

Increased communication and integration work to legitimize the IndFA within the franchise system. When the focus of the IndFA is related to strategic disagreement, legitimization can be an act of compromise through which the franchisor reduces the perceived separation between the IndFA and the firm. If successful, this can increase the IndFA member's identification with the franchisor and in turn reduce intergroup bias. We define legitimization of IndFAs, therefore, as sustained communication and contact with the IndFA, including: 1) recognition of the IndFA in franchisor documentation (above and beyond current legal requirements of naming a requesting 
IndFA in the offering circular), reference to the IndFA on websites, marketing materials, and press releases; 2) support of IndFA independence and franchisee membership in the community, and 3) integration of the association into the decision making process of the firm. All such activity will act to incorporate the IndFA into the franchise system, legitimizing both its formation and continuance. An IndFA that is legitimized by the franchisor should have higher status in the franchise system. Social identity theory posits that individuals will seek membership in high status groups as this contributes to positive social identity. Therefore members of IndFAs that have a strategic focus when legitimized by the franchisor will more strongly identify with both the IndFA and the franchisor.

However if the reason for the initial formation and the continuing focus of the IndFA is centered on the protection of franchisees from perceived opportunistic behavior of the franchisor, then attempts at legitimization by the franchisor will not increase identification with the franchisor or lessen the franchisee's identification with the IndFA. Behavior viewed as benefiting the franchisor at the cost of the franchisee can be perceived as threatening the very survival of the franchisee. Under these circumstances, actions by the franchisor to legitimize the IndFA may be perceived by its members as suspicious at best and potentially subversive, e.g., identifying leaders of the group for subsequent punitive action. Members will attribute opportunistic motives to such "legitimizing" behavior or assume that the franchisor simply wants to co-opt the group so as to relieve scrutiny of its opportunistic acts.

The franchisor's response to an IndFA's challenge to its power and authority, therefore, is a critical decision. If it chooses to legitimize the IndFA, it will succeed or fail to change the members' identification with the franchisor depending on the focus of the IndFA. When the franchisor legitimizes an IndFA with a focus on strategic disagreements, the franchisees in-group 
bias toward the association should be reduced and the franchisee should feel more a part of the franchise system. If, on the other hand, the IndFA is focused on opportunistic behavior, efforts at legitimization will be futile. This leads to the following propositions related to IndFAs:

P4: In an IndFA that is focused on strategic disagreements legitimization with the franchisor moderates the relationship between IndFA focus and identification with franchisor/IndFA. IndFAs that are legitimized by the franchisor increase an IndFA member's identification with the Franchisor and the IndFA.

P5: In an IndFA that is focused on opportunistic behavior of the franchisor legitimization has no effect on identification with the franchisor or the IndFA.

\section{The Impact of FACs}

As a form of countervailing power IndFAs in some respects resemble labor unions, with the task of negotiating with the franchisor with the purpose of protecting its member franchisee interests. Researchers looking at the impact of unions on the firm present two views, one termed the “Monopoly Face” the other “The Collective Voice” (Freeman and Medoff 1984). The monopoly face is concerned with a union's ability to raise wages above the competitive equilibrium thus adversely effecting the firm and society (Friedman 1962; Hutt 1930). Scholars supporting the view of the collective voice argue that unions can in fact be beneficial to the firm resulting in increased moral, more cooperative behavior and lower turnover among employees thus improving productivity and management (Bok and Dunlop 1970; Reynolds and Taft 1956;

Slichter 1960). "Employers of unionized workers will see that while unionism is associated with a lower rate of return on capital and less managerial flexibility, the extent to which a union is a liability or an asset depends crucially on how management responds to it” (Freeman and Medoff 
1984 p.5). It is not the union per se that leads to negative consequences for the firm but rather how the firm interacts and responds to the union. "If management uses the collective bargaining process to learn about and improve operation of the workplace and the production process, unionism can be a significant plus to enterprise efficiency. On the other hand, if management responds negatively to collective bargaining (or is prevented by unions from reacting positively), unionism can significantly harm the performance of the firm." (Freeman and Medoff 1984 p.12)

We posit that a similar choice is presented to franchisors faced with the formation of an IndFA. Divergent views of IndFAs drive firms to react to them in fundamentally different ways. The franchisor may view the association as potentially destructive and counterproductive thus seeking to destroy it, or as a positive force to improve relations and thus taking steps to legitimize it within the system. Clearly, the facts surrounding the formation of the IndFA will color these perceptions on both sides. One critical fact is whether the IndFA is formed in a system which has a fully functioning FAC. Franchisors often see no purpose in legitimizing an IndFA when it is already working with a FAC. In fact, it may see such legitimization as undermining the FAC's position. This leads to the following proposition related to IndFAs:

P6: When a FAC exists in a franchise system, the franchisor is less likely to engage in activities which legitimize an IndFA.

\section{IndFA Size and Membership}

To this point we have made the implicit assumption that all franchisees are members of the IndFA. This is clearly not the case in many systems and only true when mandatory membership in such associations is required by the franchise agreement. So, although the propositions above relate to identification of IndFA member franchisees, it is important to place the IndFA in its 
larger context. To do so we must include the size of the IndFA in the model, both with respect to its absolute size and its membership as a percentage of the system wide franchisees.

Franchisors faced with the challenge of an IndFA will likely ignore its existence if the percentage of franchisees who are members remains small. However, this does not imply that a franchisor will necessarily recognize a large IndFA as the legitimate voice of its franchisee community either. As mentioned above, official recognition is but one of the reactions open to a franchisor in its attempt to reduce the out-group bias directed toward the franchisor that can occur when franchisees identify with a group other than the franchise system itself. Nevertheless, as compared to small splinter-group IndFAs, franchisors are more likely to act to legitimize large established IndFAs that have come to represent a significant proportion of their franchisees. This leads to the following proposition related to legitimizing of IndFAs:

P7: The greater the percentage of franchisee membership in an IndFA, the more the franchisor is likely to engage in activities which legitimize an IndFA.

In his seminal work on collective action Olson (1965) argues that the smaller the group the greater per capita benefit of collective action and that the ability to provide for the optimal public good decreases as groups get larger. Smaller, newly formed groups are typically comprised of highly dedicated leaders. As groups expand, they become diluted with less committed members who free ride on the effort of the core. On average the level of dedication and identification with the group can be expected to decrease with size. In the franchising context, identified leaders and members of small IndFAs may be more susceptible to punitive actions on the part of the franchisor while non-members or quiet members of larger IndFAs who still benefit from the public good of the organization bear less risk of persecution. Reaction to this threat intensifies the identification of the members with the group. Thus, it is likely that the members of a small 
IndFA when compared to members of a large IndFA will be more committed to the cause and identify more with the IndFA. This leads to the following proposition related to member identification with IndFAs:

P8: The smaller the IndFA the greater the members will identify with it.

\section{Conceptual Model}

Considering the eight propositions we have presented we offer the following conceptual model: Insert Figure 1

\section{Illustrative Examples of two IndFAs}

\section{Toasted Sub Franchisee Association:}

Since Mr. Baber’s death a group of Quiznos franchisees have created a successor IndFA called the Toasted Sub Franchisee Association (TSFA), a vocal group whose mission is "to represent, promote, serve and preserve the interests and rights of our members of the independent Quiznos franchisee community” (http://www.toastedsubs.info). The reaction of Quiznos Corporation to the TSFA has been harsh. The TSFA posted Mr. Baber's suicide note on their website, and in return eight of the association's board members received terminations including Chris Bray, former president of the TSFA. Such actions which threaten the existence of the TSFA should promote greater identification with the franchisee association and lower identification with Quizno’s corporation. Other attempts to undermine the organization include a memo about the TSFA sent to franchisees from Quiznos.

"This group states 'that their mission is to work with Quiznos to participate in cooperative communications, coordinated efforts and a focus on common issues.' They in fact promote only their own agenda through their repeated and hostile efforts to publicly damage the goodwill and reputation of the Quiznos brand and all of you who have worked so hard to build that brand and your business." (qsrweb.com) 
A number of former Quiznos franchisees are bringing class action suits against the company claiming unfair, deceptive, and coercive practices. Quiznos has received considerable bad press regarding their handling of franchisees being accused of unfair, deceptive, and coercive business practices (Arellano; MacMillan 2007; Schatzker and Calleja 2007), and even recent articles that highlight the potential turnaround of company garner significant franchisee opposition (Weingartner 2008).

In response to poor sales, franchise lawsuits, and growth concerns Quiznos hired Greg Brenneman in January 2007, as CEO. Greg Brenneman when interviewed for QSRmagazine.com about the TSFA stated, “It's certainly not representative of the system. I don't think it's either destructive or productive. If they want that forum to talk, they can. I ignore most of that stuff and do what I think is best to drive profitability for franchise owners.” (qsrmagazine.com) In response the board of TSFA stated that "Every corporation or entity, government or private, needs its watchdog-partner, and that is but one role the TSFA plays. It is clear from the past actions of the corporation that "absolute power can corrupt absolutely..." (TSFA.org)

To this day Quiznos has made no steps towards reconciling or recognizing the TSFA. Though they have worked hard to improve their image, including hiring Brenneman in 2007 to turnaround the operation, and have increased direct communication with individual franchisees, there is still a perception among many franchisees that dissent will be punished (Maze 2008). Regarding the TSFA as a few disgruntled former Quiznos franchisees, Quiznos management has decided not to reconcile with the group. Statements from Quiznos that work to undermine the legitimacy of the TSFA often argue that it has few members, is not representative of the 
franchisee community at large, and that a FAC already exists to address franchisee concerns. Though the company is close to settling its class action settlement of all class lawsuits, which includes a commitment from the company for the funding, creation and recognition of an IndFA, the TSFA has not been included or mentioned in such discussion (Sparks 2009). This action coupled with the continued focus of the TSFA on opportunistic actions of the franchisor should; increase identification among members of the TSFA and decrease members' identification with Quiznos,

\section{The Five Concepts Council:}

The Five Concepts Council is a multi-system collaborative franchisee association that represents the interests of five franchise concepts that are licensed by YUM! Brands, Inc ${ }^{1}$. (These include: AKFCF (The Association of Kentucky Fried Chicken Franchisees, Inc.); IPHFHA (International Pizza Hut Franchise Holders Association), Inc.; FRANMAC (Taco Bell Franchise Management Advisory Council); LJS (Association of Long John Silvers Franchisees), Inc., and NAWFA (National A\&W Franchisees Association) (www.yum.com). Though not a typical IndFA in that it represents multiple franchise systems that have a single franchisor, YUM! Brands, Inc, the council was created to facilitate communication between the multiple franchisee associations and YUM! Brands on issues relevant to all franchisee stakeholders. One key focus of the Five Concepts Council is a purchasing cooperative formed in 1999, two years after the creation of Yum! Brands, and the initial catalyst for cooperation (Staff 2007). Born out of conflict regarding supply and distribution; the Kentucky Fried Chicken National Purchasing Cooperative, under the leadership of the Five Concepts Council; became the Unified Foodservice Purchasing Co-op LLC (UFPC), the largest such co-op in the world (Barkoff 2006). The collaborative

\footnotetext{
${ }^{1}$ The Five Concepts Council recently became the Four Concepts Council when Pizza Hut’s IPHFHA left to join a separate cross-brand organization.
} 
effort between multiple franchisees and the franchisor was initiated to provide greater purchasing power for the franchisee thus lowering costs and improving profitability for the system. The franchisee partnership was viewed as a true collaboration with both parties bringing valuable insights to the group.

To stress the interdependence of franchisee and franchisors, Yum! developed a partnership pact that formally states how each member will contribute to the relationship while at the same time recognizing the unique position of both franchisor and franchisee (Tichy 2002). Developing such a pact provides a mechanism through which overarching goals can be maintained and fostered among both the franchisee association and franchisor. Christian Campbell, Yum! Brands senior vice president, general counsel and secretary, and chief franchise policy officer has stated that, "It has resulted in a trusting, working relationship that has been of great benefit to both parties. And, it was a cross-brand cooperative effort between the company and franchisees that resulted in the creation of UFPC, which purchases commodities and other goods for company and franchise restaurants." (Staff 2007) As Campbell further summarized, "Our partnership with franchisees demonstrates the true power of Yum! and there is no stronger evidence of this than UFPC." Rather than focusing on regulation to guide behavior, YUM! has focused on normative control mechanisms (Tichy 2002) by creating a culture that encourages employees to be "Customer Maniacs". These norms help provide a sense of cohesion between franchisee and franchisor and this should reduce identification with a specific IndFA in favor of identification with the firm. In addition, a focus on strategic issues dealing with distribution and supply acted as the catalyst for the creation of the Five Concepts Council. Based on our model, this focus, coupled with legitimization by the franchisor, should reduce intergroup bias and identification with the franchisee association. 


\section{Discussion}

As evidenced by the preceding examples of IndFAs, communities of franchisees have become important entities within some of the leading franchise systems. However, the community construct has gained little traction in franchising literature. This omission may be due to the general perception that franchisees are independent entrepreneurs with little interest in community beyond the systems themselves. The rise and current prevalence of IndFAs provides a valuable opportunity to investigate the franchisee-franchisee-franchisor relationship triad and the effects of group identification on the franchise system. An IndFA's formation and focus and the subsequent reaction by the franchisor to its existence may result in outcomes that could greatly impact the franchise system. The study of social identification within franchise systems may shed further light on key constructs in the channels literature including satisfaction, fairness, trust, and conflict.

Research on distribution channels has used member satisfaction as a key construct to explain the morale and scope of participative behavior displayed by its members (Dwyer 1980; El-Ansary and Stern 1972; Hunt and Nevin 1974; Wilkinson 1979) and the long-term success of the channel (Dwyer 1980). Firms that use non-coercive power to control channel members will reap the positive benefits of member satisfaction. Using ones power as a franchisor to punish franchisees that form IndFAs and to reward members who distance themselves from potential instigators are both deemed coercive modes of power. The use of this type of power leads to less channel satisfaction (Dwyer 1980; Hunt and Nevin 1974; Wilkinson 1979). Furthermore, perceptions of procedural justice, the practice of due process or the way in which the franchisor interacts with the franchisee in an impartial, communicative, and open manner influences 
satisfaction in channel relationships (Kumar 1996). Franchisors that are seen to be preventing franchisees from forming IndFAs and in effect suppressing legitimate criticism may be perceived as procedurally unfair resulting in less satisfaction with the relationship. Finally, franchisors reactions to an IndFA may also impact identification within the franchise system resulting in either an increase or decrease in trust, cooperation and conflict among its members. Numerous studies have documented the influence of social categorization on various behaviors including the increase of prosocial behavior (Piliavin et al. 1981), empathy (Hornstein 1976), perceptions of trust (Insko et al. 2005) and rewards (Tajfel et al. 1971) towards in-group members. Franchisors that manage their relationships with IndFAs and other similar franchisee communities can potentially benefit from such outcomes. In this paper we have argued that IndFAs are increasingly taking a visible, active, and influential role in the franchise system. Thus research on identification with and outcomes of such community activity can contribute to a greater understanding of current franchise systems. 
Figure 1

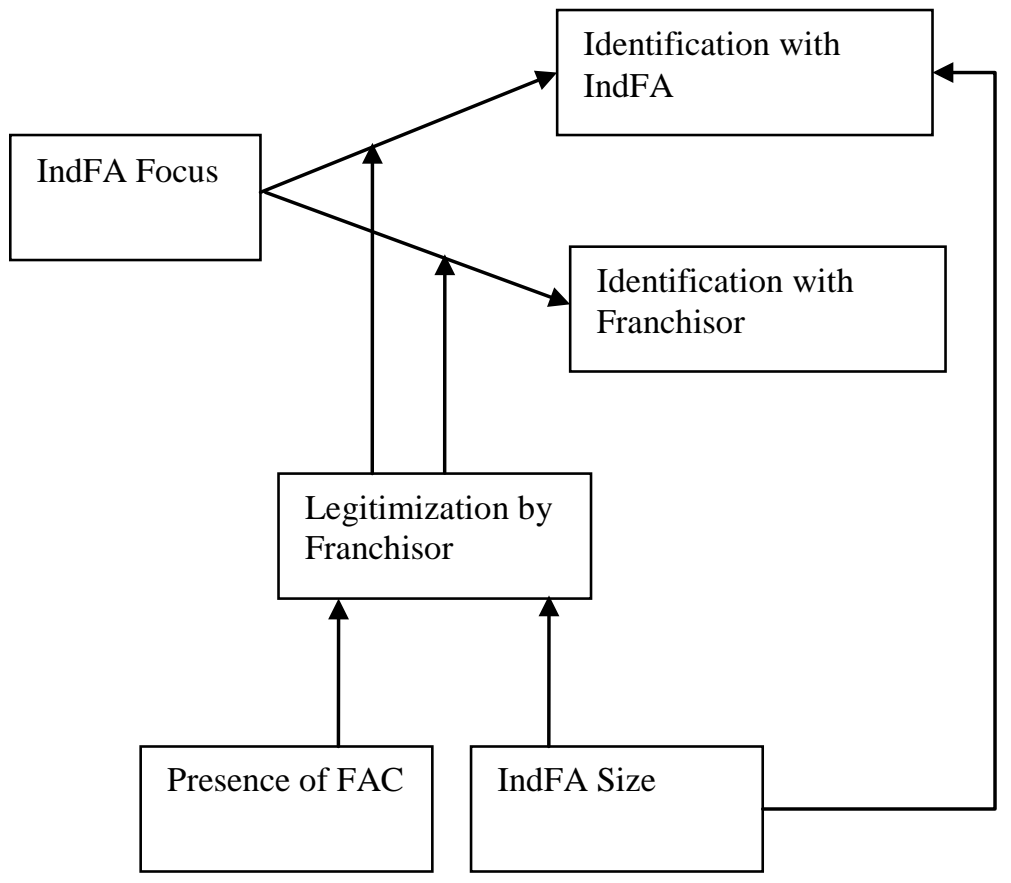




\section{REFERENCES}

Ahearne, Michael, C. B. Bhattacharya, and Thomas Gruen (2005), "Antecedents and Consequences of CustomerCompany Identification: Expanding the Role of Relationship Marketing," Journal of Applied Psychology, 90 (3), 574-85.

Allen, Robin Lee (1992), "Franchisees unite, seek political clout with new coalition," in Nation's Restaurant News.

Arellano, Kristi, "Quiznos Fires 8 Franchisees " in The Denver Post.

Barkoff, Rupert (2006), "Franchisee Associations: Nothing to Fear but Fear Itself, Usually " in Franchising World.

Berg, Eric N. (1988), "Burger King's Angry Franchisees," in New York Times

Bettencourt, B. Ann, Marilynn. B. Brewer, R. Rogers Croak, and Norman Miller (1992), "Cooperation and the Reduction of Intergroup Bias: the Role of Reward Structure and Social Orientation," Journal of Experimental Social Psychology, 28 (4), 301-19.

Bhattacharya, C. B., Hayagreeva Rao, and Mary Ann Glynn (1995), "Understanding the Bond of Identification: An Investigation of Its Correlates among Art Museum Members," Journal of Marketing, 59 (4), 46-57.

Bhattacharya, C. B. and Shankar Sen (2003), "Consumer-Company Identification: A Framework for Understanding Consumers’ Relationships with Companies," Journal of Marketing, 67 (2), 76-88.

Bok, Derek C. and John T. Dunlop (1970), Labor and the American Community. New York, NY: Simon and Schuster.

Brewer, Marilynn B. (1988), "A Dual Process Model of Impression Formation," Advances in social cognition, 1, 136.

---- (1991), "The Social Self: On Being the Same and Different at the Same Time," Personality and Social Psychology Bulletin, 17 (5), 475-82.

Brickley, James A., Sanjog Misra, and R. Lawrence Horn (2003), "Contract Duration: Evidence from Franchise Contracts," in Proceedings of the 17th Annual Conference of the Society of Franchising, Section 8.

Cartwright, Dorwin and Alvin Zander (1968), Group Dynamics: Research and Theory: Tavistock Publications.

Creswell, Julie (2007), "When Disillusion Sets In," in The New York Times.

Deutsch, Claudia H. (1988), "Franchisees Fight Back," in The New York Times.

Dutton, Jane E., Janet M. Dukerich, and Celia V. Harquail (1994), "Organizational Images and Member

Identification," Administrative Science Quarterly, 39 (2), 239-63.

Dwyer, F. Robert (1980), "Channel-Member Satisfaction: Laboratory Insights," Journal of Retailing, 56 (2), $45-65$.

El-Ansary, Adel I. and Louis W. Stern (1972), "Power Measurement in the Distribution Channel," Journal of Marketing Research, 9 (1), 47-52.

Freeman, Richard B. and James L. Medoff (1984), What do Unions do? New York: Basic Books.

Friedman, Milton (1962), Capitalism and Freedom. Chicago: University of Chicago Press. 
Gaertner, Samuel L., John F. Dovidio, Brenda S. Banker, Missy Houlette, Kelly M. Johnson, and Elizabeth A. McGlynn (2000), "Reducing Intergroup Conflict: From Superordinate Goals to Decategorization, Recategorization, and Mutual Differentiation," Group Dynamics, 4 (1), 98-114.

Galbraith, John K. (1956), American Capitalism: The Concept of Countervailing Power. Boston: Houghton Mifflin.

Greenberg, Jeff, Tom Pyszczynski, and Sheldon Solomon (1986), "The Causes and Consequences of a Need For Self-Esteem: A Terror Management Theory," Public Self and Private Self, 189-212.

Grünhagen, Marko and Robert A. Mittelstaedt (2002), "Is Bigger Better?: The Anticipation of Scale Efficiencies and Decision Participation as Motivations for Aspiring Multi-Unit Franchisees," International Journal of Entrepreneurial Behaviour and Research, 8 (3), 188-200.

Hamstra, Mark (1997), "MCD's to decentralize US management team - McDonald's," in Nation's Restaurant News.

Hayes, Jack (2004), "Blimpie operators slam policy shifts, allege kickbacks to Endervelt regime," in Nation's Restaurant News.

Hays, Constance L. (2001), "Franchisees On Edge," in The New York Times.

Hewstone, Miles and Rupert Brown (1986), "Contact is not enough: An intergroup perspective on the contact hypothesis," Contact and conflict in intergroup encounters, 1-44.

Hogg, Michael and Dominic Abrams (1993), "Towards a single-process uncertainty-reduction model of social motivation in groups," Group Motivation: Social Psychological Perspectives.

Hornstein, Harvey A. (1976), Cruelty and Kindness: A New Look at Aggression and Altruism: Prentice-Hall.

Hunt, Shelby D. and John R. Nevin (1974), "Power in a Channel of Distribution: Sources and Consequences," Journal of Marketing Research, 11 (2), 186-93.

Hutt, William H. (1930), The Theory of Collective Bargaining. Glencoe, Illinois: The Free Press.

Insko, Chester A., Jeffrey L. Kirchner, Brad Pinter, Jamie Efaw, and Tim Wildschut (2005), "Interindividualintergroup discontinuity as a function of trust and categorization: The paradox of expected cooperation," Journal of Personality and Social Psychology, 88 (2), 365-85.

Kramer, Louise (1996), "McD franchisees form indy group: aim to track new operations plan - McDonald's Corp," in Nation's Restaurant News.

Kumar, Nirmalya (1996), "The Power of Trust in Manufacturer-Retailer Relationships," Harvard Business Review, 76 (6 (November-December)), 92-106.

MacMillan, Douglas (2007), "Franchise Owners Go to Court," in Businessweek. January 29 ed.

Mael, Fred and Blake E. Ashforth (1992), "Alumni and their alma mater: A partial test of the reformulated model of organizational identification," Journal of Organizational Behavior, 13 (2), 103-23.

Maze, Jonathan (2008), "Has Quizno's Changed?," in The Franchise Times.

Muniz, Albert, M. and Thomas O'Guinn, C. (2001), "Brand community," Journal of Consumer Research, 27 (4), 412-32.

Olson, Mancur (1965), "The Logic of Collective Action ": Cambridge, MA: Harvard University Press.

Oxenfeldt, Alfred R. and Anthony O. Kelly (1968), "Will Successful Franchise Systems Ultimately Become Wholly-Owned Chains?," Journal of Retailing, 44 (4), 69-83. 
Piliavin, Jane, John F. Dovidio, Sam L. Gaertner, and R. D. III Clark (1981), Emegency Intervention. New York: Academic Press.

Reynolds, Lloyd G. and Cynthia H. Taft (1956), The Evolution of Wage Structure: Yale University Press.

Rubin, Paul H. (1978), "The Theory of the Firm and the Structure of the Franchise Contract," Journal of Law and Economics, 21 (1), 223-33.

Schatzker, Mark and Dawn Calleja (2007), "Toasted," in The Globe and Mail.

Sherif, M. (1961), Intergroup Conflict and Cooperation: The Robbers Cave Experiment: University Book Exchange.

Slichter, S. H. (1960), The Impact of Collective Bargaining on Management. Washington D.C.: Brookings Institute Press.

Sparks, Janet (2009), "Quiznos Class Actions Near Settlement," in Bluemaumau.com.

Staff (2007), "Franchise Partnership with Yum! Led to Creation of World's Largest Purchasing Cooperative," in The Nation's Restaurant News.

---- (1998), "McDonald's Corp. Creates New Franchisee Council," in The Nation's Restaurant News.

Tajfel, Henri (1970), "Experiments in Intergroup Discrimination," Scientific American, 223 (5), 96-102.

Tajfel, Henri, M. G. Billig, R. P. Bundy, and Claude Flament (1971), "Social categorization and intergroup behaviour," European Journal of Social Psychology, 1 (2), 149-78.

Tajfel, Henri and J. C. Turner (1979), "An Integrative Theory of Social Conflict," The Social Psychology of Intergroup Relations. Monterrey: Brooks/Cole.

Tichy, Noel M. (2002), The Cycle of Leadership: How Great Leaders Teach Their Companies to Win. New York: Collins Business.

Weingartner, Nancy (2008), "Where’d All the Quiznos Letters Go?," in The Franchise Times.

Wilkinson, Ian F. (1979), "Power and Satisfaction in Channels of Distribution," Journal of Retailing, 55 (2), 79-94. 